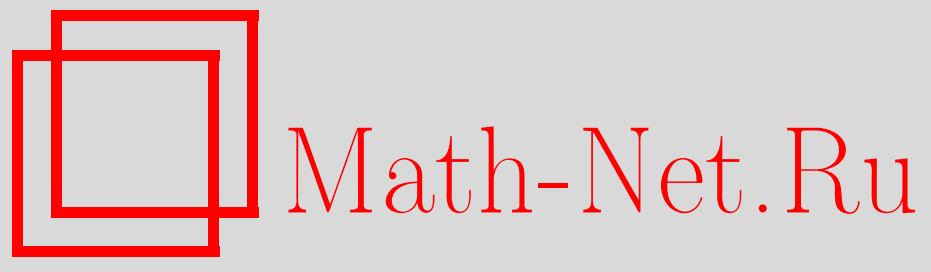

Е. И. Каликинская, Встречи с Марком Вишиком, УМН, 2014, том 69, выпуск 6, 197-204

DOI: https://doi.org/10.4213/rm9638

Использование Общероссийского математического портала Math-Net.Ru подразумевает, что вы прочитали и согласны с пользовательским соглашением http://www . mathnet.ru/rus/agreement

Параметры загрузки:

IP : 35.174 .16 .151

26 апреля 2023 г., 15:48:20

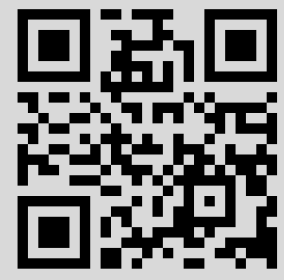




\title{
Встречи с Марком Вишиком
}

\begin{abstract}
Марк Иосифович Вишик был научным руководителем моего мужа Владимира Чепыжова, когда он учился на мехмате МГУ, а после они работали вместе в течение почти 30 лет. Поэтому, не будучи математиком, я нередко общалась с ним - говорила по телефону, встречалась в совместных поездках и на немногочисленных общих праздниках. В последние годы его жизни, когда Марк Иосифович остался без своего верного друга и преданной супруги, мы с мужем решили навещать его регулярно, чтобы скрасить подступившее одиночество; так же поступали и многие другие его знакомые. Без преувеличения могу сказать, что Марк Иосифович любил поговорить со мной о делах житейских, вспоминать об Асе Моисеевне, друзьях и родных, рассказывать о своей молодости, о замечательных встречах, которыми была так богата его жизнь. $\mathrm{У}$ нас возникла идея записать беседы с ним и потом оформить их в виде книги. $\mathrm{K}$ сожалению, встреч с ним предстояло уже не так много. Последняя наша беседа состоялась в январе 2010 г. Книги не получилось, но получилась статья [1], опубликованная на английском языке в виде интервью с Марком Иосифовичем.

В этой статье я попытаюсь передать его воспоминания о людях, которые играли важную роль в его жизни, на материале наших бесед.
\end{abstract}

\section{Иван Георгиевич Петровский}

Он был для Марка Иосифовича человеком, который деятельно и сердечно помогал ему в трудных ситуачиях в начале и середине его научного пути, великим ученым и руководителем, память о котором Марк Иосифович хранил благодарно и благоговейно. Для него это был и человек-легенда, и в то же время близкий человек, которого он всегда старался понять, которого вспоминал чаще других.

Марк Вишик рассказывает: Когда в 1945 г. я переехал в Москву, то все время проводил в старом здании университета на Моховой. Петровский тогда был деканом механико-математического факультета и заведующим кафедрой дифференциальных уравнений. Он читал в университете лекции по уравнениям с частными производными и написал три книги, посвященные обыкновенным дифференциальным уравнениям, уравнениям с частными производными и интегральным уравнениям. (В это время ректором университета был некий Галкин, которым в университете были недовольны.) Иван Георгиевич произвел на меня с первого взгляда огромное впечатление. Я знал, что это крупнейший ученый, в "Успехах математических наук" читал его только что вышедшую статью, где он изложил основные направления развития математики в ближайшее время.

Я ежедневно бегал на своих двоих из дома жены на Сивцевом Вражке до университета. Не пропускал ни одного семинара Петровского, ни одной его лекции по обыкновенным дифференциальным уравнениям и уравнениям с частными производными! На семинарах Петровского в основном выступали его ученики. Помню Геню Ландиса, который ходил на семинары в военной форме. Там были также Ольга Олейник, Анатолий Мышкис. Был еще малый семинар.

DOI: $10.4213 / \mathrm{rm} 9638$ 
Ко мне Иван Георгиевич отнесся очень доброжелательно, несмотря на то, что я тогда не очень хорошо говорил на русском языке, поскольку кончил польскоязычную гимназию во Львове, хорошо знал украинский и немецкий, а русский стал учить в Грузии, так что он был у меня своеобразный. (Научную литературу на русском языке я читал свободно.)

Семинар Петровского проходил на очень высоком уровне. Он следил за тем, чтобы темы семинаров касались общих крупных проблем, он сам был одним из тех, кто решил одну из проблем Гильберта. Многие решали эту проблему для частных случаев, например, Сергей Натанович Бернштейн, а Иван Георгиевич доказал ее для общих систем.

Обстановка на семинарах Петровского была необыкновенно дружеская, и каждую неделю были докладчики. Но в те дни, когда их почему-то не хватало, я всегда вызывался сделать доклад, и Иван Георгиевич очень ценил такую мою деятельность на его семинаре и порой по-отечески опекал меня.

Я был счастлив, что оказался в Московском университете. Прежде всего меня поразил высокий уровень математики в МГУ. Поэтому я ходил на все семинары, какие только было можно - и к Абраму Иезекииловичу Плеснеру, и к Лазарю Ароновичу Люстернику, и к Израилю Моисеевичу Гельфанду. А также на заседания Московского математического общества, на лекции для студентов, которые в качестве общественной нагрузки читали известные математики, например Андрей Николаевич Колмогоров. В то время я занимался математикой по двенадцать часов в день.

Иван Георгиевич сыграл важную роль при защите моей кандидатской, а также и докторской диссертации. Когда в 1947 г. я подготовил кандидатскую, он сам стал ее оппонентом. (Другим оппонентом был академик Сергей Львович Соболев, с которым я познакомился в 1946 г.)

Петровский с большой добротой помог мне и в 1951 г., когда я закончил докторскую диссертацию. Официально я был прикомандирован к Институту им. В. А. Стеклова и отнес свой труд куда положено. Я никогда не интересовался никакими интригами, вообще человеческими отношениями, и мне было невдомек, что место это совсем для меня неподходящее. В ту пору я совершенно не представлял себе, что людей с пятым пунктом в анкете в Стекловском институте очень не любят, что нечего даже и думать там защищаться!

Ученый секретарь принял мои бумаги, но сухо сказал, что Ученый совет очень загружен. Он даже отказался брать у меня все четыре экземпляра диссертации, а взял только один, добавив, что мне позвонят, когда дело сдвинется с мертвой точки. Я загрузил "ненужные" три экземпляра в портфель тестя (своего у меня в ту пору не было) и пошел домой. Было это в январе месяце. Конечно, никаких звонков мне не последовало. Дело казалось безнадежным. Прошло полгода - молчание. Как-то на семинаре Петровский спросил, как продвигается дело с моей докторской диссертацией. Я поведал, что жду звонка из Стекловки. Тогда Иван Георгиевич, ни слова мне не сказав, сел на свою ректорскую машину и поехал к академику Ивану Матвеевичу Виноградову, высказать свое мнение обо мне и моей научной работе. И в тот же день мне позвонил ученый секретарь! Он потребовал, чтобы я немедленно принес характеристику, остальные три экземпляра диссертации... Процесс пошел! Разговор мой с Петровским был где-то в июне, ученый совет летом не заседает. Но в октябре я уже защищался.

Академик Виноградов не мог не послушаться академика Петровского - у него было всего пять этажей в институте, а у Петровского, который к тому времени стал ректором МГУ, чуть побольше. А в будущем стало и совсем много.

Этот эпизод очень характерен для Ивана Георгиевича. Он всегда активно вмешивался в то, что казалось ему несправедливым. При этом действовал быстро и решительно, не дожидаясь, что его об этом попросят. Например, его ученик Геня Ландис, 
которому пятый пункт также "мешал" работать в МГУ, был зачислен на кафедру дифференциальных уравнений только по личной инициативе Петровского.

Запомнился и такой эпизод из моей молодости. Когда я еще учился в университете, учебник Петровского по уравнениям с частными производными только готовился к изданию, и нам раздавали на лекциях листы из будущей книги. Один студент нашел в учебнике ошибку и сказал об этом Ивану Георгиевичу. Петровский не только поблагодарил его за это, но и выразил студенту благодарность в тексте учебника. Вот каким он был человеком! Истина для него была важнее всего.

Иван Георгиевич совсем не изменился, когда стал ректором университета. Каким он был деканом - заботливым, человечным, таким же он стал и ректором. Ему не раз предлагали быть ректором, но он отказывался, потому что хотел заниматься научной работой и в то время активно работал в науке. А в годы войны, когда университет был эвакуирован в Казань, Петровский был деканом мехмата и показал себя отличным руководителем. Он заботился не просто об абстрактных вещах, а именно о куске хлеба для каждого сотрудника. И во время войны ему еще раз предложили стать ректором. Но он снова отказался.

Тогда партийные деятели МГУ пошли на прием к товарищу Сталину и доложили, что предыдущий ректор не устраивает университетскую общественность. Сталин якобы спросил:

- Есть человек, который был бы и крупным ученым, и хорошим руководителем?

- Есть, но он отказывается.

- Назовите его фамилию.

- Иван Георгиевич Петровский.

Согласно легенде, Сталин взял листок бумаги и написал на нем: "Назначить ректором МГУ И. Г. Петровского". И в тот же день Ивана Георгиевича стали поздравлять с назначением его коллеги, хотя официально объявлено еще не было, требовался еще долгий путь введения его в должность. Но отказаться он уже не мог. К тому же Петровский всегда думал о том, как больше пользы принести университету. Однажды Иван Георгиевич сказал мне: "Я решил: если я останусь заведующим кафедрой, я сделаю десятки крупных научных работ, а если стану ректором - в университете будут сделаны тысячи таких работ". Это решило дело.

Благодаря Петровскому я стал преподавать в МГУ, хотя не сразу. После окончания университета меня направили в Московский энергетический институт, но в 1951 г. всех профессоров с пятым пунктом, кроме членов партии, стали увольнять. Например, В.И. Левина, зав. кафедры высшей математики в МЭИ, уволили. Я тоже был в списке на увольнение. Но ректор, профессор Михаил Григорьевич Чиликин, меня вычеркнул, поскольку я делал большую работу. На место Левина назначили Н. А. Леднева, такого математического Лысенко. Он на каждом семинаре и заседании кафедры громил Петровского и Соболева и обещал выгнать всех, кто с пятым пунктом. А про меня кто-то пустил слух, совершенно несправедливый, разумеется, что я - лучший друг Леднева. И благодаря этому меня не уволили.

В 1965 г. Петровский решил обновить свою кафедру и стал советоваться с Гельфандом, кого взять для укрепления преподавательского и научного состава. Тот сказал: "Ясно кого - Вишика!" Иван Георгиевич осторожно спросил: "Но ведь он лучший друг Леднева?" "Кто Вам сказал? Это неправда. Более надежного человека, чем Вишик, не знаю", - ответил Гельфанд. Это решило дело. В тот же день Петровский позвонил мне домой и сказал, что я должен сделать, чтобы стать профессором его кафедры. И уже в июне я им стал.

Наши отношения были очень хорошими до конца его дней, я часто бывал дома у Ивана Георгиевича, был хорошо знаком с его женой Ольгой Афанасьевной. Он был очень образованным, очень культурным человеком. И неожиданно для меня человеком верующим. В одной из комнат у него висело большое полотно Корина с изображением каких-то монахов. Впечатление от этой картины у меня было огромное. 
Петровский очень любил музыку Баха. Я помню, как один аспирант возмущался: приходишь к Ивану Георгиевичу, а он два часа может слушать Баха! Одного Баха. Он считал, что это кладезь. Я тоже очень люблю Баха. Его можно слушать даже после Бетховена. Но когда мы ездили в Париж с Ольгой Арсеньевной Олейник, то Иван Георгиевич просил всегда, чтобы мы тайком привезли ему на пластинках богослужебные песнопения православной церкви.

У меня в то время возможность ездить за границу была тоже благодаря Ивану Георгиевичу. В 1967 г. Игорь Ростиславович Шафаревич, большой математик, приехал из научной командировки из Франции и сказал: "Французы хотят пригласить Вишика". Мы в ту пору занимались очень интересными вещами с Гришей Эскиным и Михаилом Семеновичем Аграновичем. И французы меня знали очень хорошо, потому что Жак-Луи Лионс, их руководитель, талантливый руководитель и организатор, глава направления, был учеником Лорана Шварца, который ввел в науку обобщенные функции. Соболев у нас это направление тоже отчасти развивал, но Лионс сделал из этого науку. Они пользовались сразу обобщенными функциями и очень нас опережали. У нас Ладыженская работала в $H^{1}$, а они работали в $H^{s}$ - целая шкала пространств до бесконечности.

Когда я впервые в 1967 г. поехал во Францию, это было очень сложно организовать. Но И.Г. Петровский послал меня в обмен на какого-то французского гостя, кого - не знаю, не интересовался. Иван Георгиевич лично ручался за меня. Тогда были на этот счет строгие правила. Одна дама в администрации университета занималась только тем, что командировки за рубеж оформляла, соблюдая эти правила. Например, можно было провести за границей не больше месяца в год. Если две недели провел в Болгарии, то можно потом еще две недели в Швеции. Был случай, когда я был приглашен Ларсом Гордингом на месяц, но уже "потратил" две недели, и дама мне сказала: "Я бы с удовольствием, Марк Иосифович, но не могу: вам положено только месяц в год".

А Ивану Георгиевичу было все равно - еврей ты или русский, православный или другого вероисповедания, бунтарь или лояльный к власти человек. Ему было важно одно: чтобы в университете работали самые способные люди.

Иван Георгиевич до последних дней руководил и кафедрой, и семинаром. На семинары он порой очень сильно опаздывал, мы ждали его иногда по часу. Ничего не поделаешь - ему нужно было решать огромные административные проблемы. Но он всегда приходил. K концу доклада обычно спрашивал у выступавшего, насколько налагаемые им условия являются существенными. Он уважал только настоящие теоретические работы. А с другой стороны, очень приветствовал прикладные исследования, например по математической физике. Помню, очень понравился ему доклад профессора Сергея Константиновича Годунова из Новосибирска, который впоследствии стал академиком.

Когда Петровский был ректором, к нему на прием можно было попасть в любое время. У него не было дней или времени приема - он всегда был открыт людям и проблемам университета.

Иван Георгиевич, по-моему, был велик и как руководитель. Его интересовало только одно - чтобы человек принес университету пользу. Не играла роль ни национальность, ни партийность, ни происхождение - только научный вес. Его друзьями были Гальперин и Крейнис. В то время шла компания против евреев в науке, и на физический факультет уже давно не принимали ни преподавателей, ни студентов с пятым пунктом. А Иван Георгиевич настоял, чтобы на физфаке начали преподавать Ландау и Лифшиц - они сами и не очень-то хотели отвлекаться от науки. Но по инициативе Ивана Георгиевича сделали такое великое дело. Академик Шкловский как-то подсчитал, что за время своего ректорства Иван Георгиевич сделал не менее 10 тысяч добрых дел. 
Все эти заботы сократили его жизнь на несколько лет. Ведь у него было больное сердце, но он не жалел себя, до всего доходил сам. Например, боролся за то, чтобы для приема в университет сдавали не один устный и один письменный экзамен, а два письменных. На устном экзамене кого угодно можно было завалить. По этому поводу Иван Георгиевич постоянно ходил в ЦК партии, просил изменить процедуру экзаменов. Ему отвечали: "Вы, Иван Георгиевич, крупный ученый и руководитель, но вопрос, сколько экзаменов сдавать в университет - не ваш вопрос". Во время одного из таких приемов ему стало плохо, у него случился сердечный приступ прямо в здании ЦК. Он упал на пол. Его стали поднимать: служащие пытались посадить его на стул - нехорошо тут лежать, не положено. Если бы вызвали сразу врачей и не поднимали, может быть, и удалось бы спасти. А из-за этой проволочки получилось так, что упустили драгоценное время.

Я не помню, чтобы Петровский когда-нибудь праздновал свои юбилеи. Но я очень хорошо помню его похороны. Играл великий скрипач Леонид Коган - "Элегию" французского композитора Жюля Массне. Я стоял прямо за его скрипкой. Приехали специально из ЦК партии - Михаил Андреевич Суслов. Я чуть вышел из зала, чтобы посмотреть, что творится, как вдруг стали всех теснить и говорить: "Проходите, проходите". Так страховали приход Суслова и хотели, чтобы лишних людей там не было в этот момент. У них были свои правила.

\section{Стефан Банах}

Еще один человек-легенда, с которым М.И. Вишику посчастливилось познакомиться в юности. Гениальный ученый и преподаватель университета, с лекиий которого, возможно, началось знакомство Марка Иосифовича с наукой. А также человек одного с ним духа, одних жизненных иелей.

Марк Вишик рассказывает: В Львовском государственном университете, в который я поступил в 1939 г., деканом математического факультета тогда был Стефан Банах, гениальный математик. Кроме него нам преподавали самые выдающиеся профессора Банаховской школы: Бронислав Кнастер - аналитическую геометрию, Юлиуш Шаудер - теоретическую механику, профессор Станислав Мазур - дифференциальную геометрию. Профессор Владислав Орлич читал лекции по алгебре. Все это преподавание было на польском языке. Только заместитель декана профессор Мирон Зарицкий читал на украинском.

Я ходил на все лекции Банаха, и они вызывали у меня чувство необыкновенного счастья: я могу учиться в таком университете! Ведь Банах уже при жизни считался первым классиком польской математики...

Однако показывать свое величие - это было ему не свойственно. Ему были свойственны простота, дружелюбие и веселость, у него было прекрасное чувство юмора. Когда шел его семинар, он постоянно вмешивался, задавал вопросы, мог дружелюбно подшутить над докладчиком. Но никто этого не боялся, общая атмосфера была очень веселая и располагающая. Еще Банах любил перед семинаром спрятать портфель профессора Станислава Сакса, чтобы потом тот его искал и можно было немного повеселиться по этому поводу.

Каждый день они с профессором Зарицким отправлялись обедать, и, когда возвращались, было ясно, что они позволили себе немножко и выпить. Он был очень жизнелюбивым человеком, большим, шумным, громогласным.

У него была требовательная жена, отчасти из-за этого он писал не только научные книги, но и учебники для средней школы, а также книги по механике. Но это было ко всеобщему благу: на его прекрасных учебниках выросло не одно поколение. Профессор Шаудер по книге Банаха читал нам прекрасные лекции. Нам очень повезло, что мы учились по этим книгам. Шаудер тоже очень уважительно обращался со студентами: каждый раз перед новой лекцией просил, чтобы кто-то из студентов, кто хочет, изложил основы предыдущей лекции или теоремы, которые были пройдены. И только после этого начинал следующую лекцию. 
Большое впечатление произвели на меня также семинары Абрама Плеснера, он репатриировался из Варшавы в Россию, а потом я с ним встретился в МГУ, где он стал профессором. Помню, он дал мне реферировать статью Германа Вейля (считалось, что после Гильберта он будет руководить в Гёттингене). Тогда считалось хорошим тоном, сделав работу, отправляться с докладом к Гильберту в Гёттинген.

Однажды Банаха и Шаудера вызвали в Киев и поставили им задачу "советизировать" львовский университет. Вернувшись, они ничего особенного не сделали по идеологии, а решили усилить работу так: организовать студенческие конференции, которых у нас тогда не было. Профессор Эдвард Шпильрайн собрал студентов и рассказал нам про хаусдорфовы пространства. Так было положено начало студенческим конференциям. Банах тоже посещал эти конференции и очень весело реагировал на студенческие замечания по этим вопросам.

После войны, в 1945 г. в Москве, я еще раз виделся с Банахом. Его пригласил приехать академик Колмогоров, который хотел, чтобы Банах преподавал в МГУ. Банах тогда остановился в университетской гостинице на Тверской, и я туда к нему приезжал. Он был неузнаваем - сильно похудел, стал каким-то плоским, одномерным. Рассказывал, что в годы войны спасся тем, что кормил вшей. Фашистские врачи во Львове ставили эксперименты на людях: изучали действие вшей на организм, чтобы спасти от них свою армию. И кто-то устроил Банаха к этим врачам, чтобы спасти его от гибели. Ему привязывали на руку мешочек со вшами, и он должен был их кормить. За это ему даже как-то платили, так что он мог поддерживать семью и выжить сам.

Но тогда все эти ужасы остались позади, и первое, о чем меня спросил Банах: что я читал по математике во время войны? Я описал ему мои научные интересы, и он сказал: "Будьте как Шаудер - занимайтесь методами функционального анализа и дифференциальными уравнениями".

В тот же год Банах умер от рака легких. Он очень много курил.

В 50-е годы я ездил читать лекции в центре имени Банаха, в Математическом институте польской Академии наук. Меня пригласил ученик Банаха профессор Владислав Орлич - он был профессором в Познани, потом вернулся во Вроцлав. После лекций мы с ним обсуждали, как нужно помогать аспирантам. В то время было очень строго и в Польше, и у нас - руководитель аспиранта должен был обеспечить ему защиту кандидатской диссертации. Орлич спросил, сколько у меня аспирантов. Я ответил - шесть. У него тоже было шесть. Он спросил еще, что я делаю, если аспирант не дотягивает. Я сказал, что помогаю. Он признался, что тоже помогает. Мы были счастливы, что делаем одинаково.

\section{Жак-Луи Лионс и Жан Лерэ}

К своим замечательным франиузским коллегам Марк Иосифович относился доброжелательно и с уважением, но иногда любил над ними добродушно пошутитъ. Они были моложе его и, по его мнению, нередко шли по проторенным им путям. Марк Иосифович по природе своего выдающегося ума был первооткрывателем в науке, часто "прокладывал путь по челине", и его идеи ложились в основу фундаментальных работ других ученых. Он говорил об этом с доброй улыбкой, без какой-либо обиды. В работе франиузских математиков многое ему импонировало, да и личные отношения складывались оченъ тепло.

Марк Вишик рассказывает: В 1967 г. я впервые оказался во Франции, в Парижском университете "Пари-6". Там Лионс, профессор этого университета, написал пять или шесть книг исходя из наших совместных работ с Соболевым и моих работ. Когда-то я придумал, как решать эти задачи и написал академику Соболеву. А он взял и сам приехал ко мне домой. Я тогда еще жил у родителей жены на Сивцевом Вражке, в одной комнате с двумя детьми. И вот приезжает академик, на черной "Волге" с шофером, и садится рядом со мной за один стол решать задачи. В этом эпизоде видно, каким Соболев был настоящим большим ученым. Он был счастлив 
заниматься чистой наукой, ему надоела работа в Курчатовском институте, где он заведовал отделом, и были безразличны условности. Соболев занимался обобщенными задачами для гиперболических и для эллиптических уравнений.

Вышли у нас две заметки по этому поводу, а Жак-Луи Лионс и Энрико Мадженес после много работали и написали три тома по этой теме. Соболев предлагал написать на эту тему статью побольше, но я не мог, потому что в это время работал с Люстерником над пограничным слоем, к тому же считал, что в наших заметках уже все есть.

Приняли меня во Франции замечательно. Французских математиков очень интересовало, чем мы занимаемся и что мы думаем. Там был молодой человек Ален Аро, который заинтересовался моими исследованиями и после сделал по этой тематике очень хорошую работу. Мы с ним стали друзьями.

Лионс тогда был довольно молод. Он был очень образованным человеком. У французов есть одна замечательная черта: они очень много знают и великолепно эрудированны. У нас чаще человек сам все придумывает, а эрудиция не важна. У них сочетается обычно и эрудиция, и собственный талант. И это имеет корни во французской истории: в XIX в. во Франции было много огромных математиков: Лаплас, Лагранж, Коши, Галуа. Французские математики - глубоко образованные люди, и их очень интересуют новые идеи.

Лионс происходил из города Грасс, где его отец был мэром. Когда пришли фашисты, они первым делом арестовали его отца, чтобы он не организовал сопротивления, и он всю войну просидел в тюрьме. А сам Лионс, хотя и был в ту пору 15-летним парнем, пошел в маки - партизаны. И партизанил в горах против фашистов.

Он ко мне очень хорошо относился и пригласил к себе домой. Пока жена его готовила этот прием, она звонила, чтобы мы задержались на пару часов, потому что она не успевает все как следует сделать. Тогда Лионс пришел в мой кабинет и сказал: расскажите мне тогда пока про интерполяцию. Я пошел к доске и стал объяснять.

Наконец мы отправились домой к Лионсу, куда пришли еще известные французские профессора и сказали: "Марк Иосифович, как мы вам благодарны! Мы первый раз дома у Лионса благодаря Вам. Если бы не Вы, мы бы тут не побывали".

А Лионсу когда-то подарили винный погреб в Грассе. В таком погребе хранится вино 40-летней давности. Но если ты берешь оттуда бутылку, ты должен заложить взамен бутылку одного из лучших вин ближайшего года. Это французский закон: погреб должен жить для будущих поколений. И Лионс иногда привозил из Грасса запыленные старинные бутылки, заворачивал их в прекрасную бумагу и после угощал знатоков.

$\mathrm{K}$ сожалению, я не гурман и ничего не понимаю ни в еде, ни в вине. Вообще не гожусь для таких дегустаций, потому что у меня больная печень с военных лет, в Дагестане я болел малярией, ел хинин, от которого и слух портится, и печень. Поэтому я не могу пить хорошего вина. После моей лекции меня пригласили как-то в Коллеж де Франс, в знаменитый ресторан на берегу Сены, они делают свое вино из виноградников на берегу. Меня хотели удивить вином знаменитой марки. Всем торжественно разлили вино в бокалы. А я на глазах и изумленных французов разбавил его водой. Под крики: “Что вы делаете? У вас же лягушки заведутся в животе!" Но я, к сожалению, не мог пить этого вина из-за больной печени.

Я посетил Коллеж де Франс, там руководил кафедрой академик Жан Лерэ. Он работал вместе с Шаудером, моим первым учителем и первым консультантом. И когда я приехал во Францию, Лерэ меня сразу пригласил в ресторан. Он очень любил Шаудера, и он знал, как Шаудер погиб: в гетто, его затравили собаками. С Лерэ мы говорили на математические темы, он интересовался, чем я занимаюсь, и угощал чрезвычайно обильно. Я не привык так есть. Когда после прекрасного обеда дали еще мороженое и целый тазик с шоколадом, я уже не мог ни к чему прикоснуться.

Лерэ интересовала проблема трехмерного уравнения Навье-Стокса. Он говорил, что невозможно доказать гладкость решения системы для больших чисел Рейнольдса. Лионс сделал это проблемой века. 
Потом я еще несколько раз общался с Лерэ. Ему очень нравилось, когда я приезжал и рассказывал свои идеи, он принимал меня всегда восторженно.

Во Франции я впервые понял, что новая идея - огромная ценность. У нас в Москве в то время так не считалось. Я докладывал на семинарах Петровского, Тихонова, Люстерника, Плеснера и везде рассказывал о том, что у меня выходит, не думая о том, опубликовано или нет, сдано ли в печать, не говоря уж о том, что работа еще год могла лежать в редакции, ожидая очереди на опубликование. У французов же самым неприличным вопросом был вопрос: скажите, чем вы сейчас занимаетесь? Это тайна, спрашивать об этом нельзя. Прошлое, уже опубликованное - пожалуйста.

Итак, во Франции я понял цену новых идей. Я по природе своей генератор идей и не любил читать много. Я считаю себя малообразованным математиком: хотя ходил на много семинаров, но статьи читать не любил. Что-нибудь свое придумаю и лишь тогда посмотрю - что другие сделали на эту тему. А не наоборот, как принято. Этой моей способности все удивлялись.

\section{Ася Моисеевна Гуттерман}

Значение этой удивительной женщины в жизни великого ученого переоценить невозможно: она была и женой, и другом, и немножко - матеръю (родители Марка Иосифовича погибли в 1941 г. в гетто), и хранителем, и катализатором. Марк Иосифович гордился тем, что жена его во время войны работала рентгенотехником, считал ее авторитет непререкаемым по медииинским и иным вопросам. Я всегда с удовольствием общалась с Асей Моисеевной - глубоко интеллигентной, тактичной, тонко чувствующей женщиной. Она и ее близкие родственники - в первую очередъ, конечно, Иосиф Абрамович Овсеевич - создавали ту среду, в которой Марк Иосифович мог безмятежно существовать. После ухода Аси Моисеевны он, как "простой смертный", стал более уязвим для травм и болезней, стала слабеть его память, лишенная общих воспоминаний. Хотя ему был обеспечен хороший уход и внимание, время от времени Марк Иосифович с удивлением сообщал мне, что "теперь приходится заниматься хозяйством, теперь я знаю, где стоят чашки и заварочный чайник, а при Асенъке я этого не знал". Ее неустанной и самоотверженной заботы ему, конечно же, не хватало.

Марк Вишик рассказывает: С Асей мы прожили вместе счастливо и безмятежно 62 года. Были во всем едины с того самого дня, как встретились в День Победы в 1945 г. в университете, до ее ухода в 2009 г. Я иногда в шутку говорил, что Асенька меня на себе женила и тем спасла от голода и гибели. После той ужасной жизни, которая была у меня во время войны, я попал в прекрасную семью, у меня появился дом. И Ася всегда брала на себя все, что касается быта, я никогда не знал, где у нас что лежит, откуда что берется. Я был от всего этого освобожден, чтобы заниматься наукой. Асенька в нашей обыденной жизни была генералиссимусом: она решала все проблемы, кроме научных. И конечно, мне просто невозможно представить, как я буду обходиться без нее...

\section{Е.И. Каликинскал}

\section{Список литературы}

[1] E. Kalikinskaya, "Interview with Mark Iosifovich Vishik", guest editors A. Miranville, V. V. Chepyzhov, Commun. Pure Appl. Anal., 13:5 (2014), i-x. 